\title{
Analysis of Combined Pile Raft Foundations Based on a Static Load Test
}

\author{
Zygmunt Meyer, Piotr Cichocki* \\ Faculty of Civil Engineering and Architecture, West Pomeranian University of Technology in Szczecin, Poland
}

Received December 29, 2019; Revised March 30, 2020; Accepted April 9, 2020

Copyright $\odot 2020$ by authors, all rights reserved. Authors agree that this article remains permanently open access under the terms of the Creative Commons Attribution License 4.0 International License

\begin{abstract}
Combined pile raft foundations (CPRF) take into account the synergy of a raft with a group of piles in transferring the load to the ground. In many ground conditions, such foundations are optimal in both utilitarian and economic terms. Based on a literature review, it can be concluded that, despite the numerous extant calculation methods for the analysis of piled raft foundations, there is lack of research related to the possibility of using a load-settlement curve from a static pile test in the full range, in order to analyse the load-settlement curve of a pile working in a group under the raft. Furthermore, the current trend in the design of pile foundations, based on the static load test databases, encourages the formulation of methods using the results of the static pile test. These methods allow for analyses closer to the physical model. In this paper, the above research postulate was answered, formulating a mathematical model in which a particular emphasis was placed on the actual work of a single pile in the ground, taking into account the interaction among raft, piles and subsoil. The developed mathematical model was verified on the basis of the results of field research. For this purpose, the results of settlement of two tanks were used.
\end{abstract}

Keywords Combined Pile Raft Foundation, Settlement, Numerical Model

\section{Introduction}

The development of new methods for the analysis of combined pile raft foundations is aimed at increasing the accuracy of calculations and, consequently, their practical significance. Newly developed methods, and often programs based on them, should contribute in the decision-making process during the design and optimisation of structures. An integral part of choosing the final structural solution is the experience of the designers who are aided by the development of calculation methods. Therefore, being aware of the benefits of the synergy between foundation rafts and a group of piles in transmitting the load to the ground, both in utilitarian and economic terms, this article delves into one of these methods.

So far, many methods have been developed for the analysis of piled raft foundations, which can be divided into: simplified (Terzaghi\&Peck [24], Poulos\&Davis [17], Randolph [3,18]), approximate (Butterfield\&Banerjee [1], El Gendy, Hanisch\&Kany [4], Clancy\&Randolph [3,5]) and detailed (Ottaviani [15], Katzenbach et al. [6,7], Reul\&Randolph $[19,20])$. On the basis of the literature review, it can be concluded that an approach taking into account the non-linear characteristics of pile behaviour in the form of load-settlement curve from the static test of the pile with the analysis of mobilization of skin and base resistance has not yet been applied in the examination of piled raft foundations.

Moreover, it is worth noting that it is common practice to reduce field studies to the analysis of the work of a single pile on the basis of a static load test. It is important to develop a method using the results of the static test of a single pile to analyse the load-settlement curve of the pile working within the group under the raft. An additional advantage would be that the curve extrapolating the results of the load test would be used for the limit resistance. This would enable the determination of the foundation safety factors but also, if necessary, optimise the piling plan.

The presented article is based on the dissertation [2] of one of the authors of this paper. The aim is to present a method of analysing combined pile raft foundations using the static load test curve as a boundary condition of the solution. The way to achieve this is through the development of a mathematical model based on assumptions, which is systematically reviewed, and its application. The thesis put forward is that it is possible to use with sufficient accuracy, for practical purposes, the load-settlement curve from the static load test of a pile in full range to the analysis of the load-settlement curve of a pile occurring in a group of piles under the raft. 


\section{Mathematical Description of the Settlement of Combined Pile Raft Foundations}

The mathematical model of the cooperation of a combined pile raft foundation with subsoil is based on the differential equation of the plate deflection surface on elastic supports (Figure 1), under the vertical load uniformly distributed on the surface [16]:

$\frac{\partial^{4} s(x, y)}{\partial x^{4}}+2 \frac{\partial^{4} s(x, y)}{\partial x^{2} \partial y^{2}}+\frac{\partial^{4} s(x, y)}{\partial y^{4}}=\frac{q_{0}(x, y)}{D_{b}(x, y)}-\frac{k(x, y)}{D_{b}(x, y)} \cdot s(x, y)$

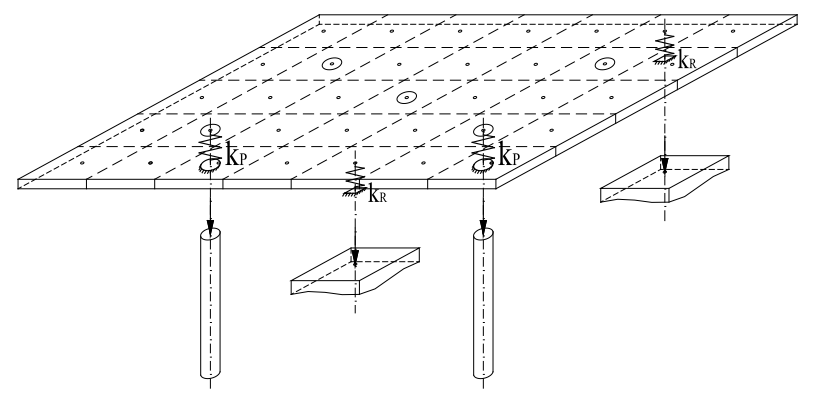

Figure 1. Scheme of a plate on spring supports modelling subsoil and piles

The analysis of an elastic raft resting on subsoil and piles requires knowledge of the stiffness of the ground medium and the piles embedded in it. In order to determine this, information on the interaction between the elements forming the foundation is needed. In the studies conducted, this was expressed in the form of partial settlements obtained by appropriate integration of stress distribution in the subsoil. For this purpose, the raft is divided into elementary fields. At the centre of each field and piles, a calculation profile is placed. In each profile, the settlement of the subsoil and piles is the sum of the partial settlements generated by all fields and piles forming the foundation. The stiffness of the supports was determined as the ratio of contact stress of the elementary field on the subsoil or piles to the node settlement in the given profile.

The mathematical description is based on the following assumptions:

- flexible raft rests on elastic half-space subsoil and compressible piles

- non-linear reaction of pile under raft is the result of a static load test and the interaction between raft, piles and subsoil

- raft-subsoil contact pressure is the result of non-linear compounds describing the loss of stress in the ground based on Boussinesq's theory and Meyer's active zones

- magnitude of settlements results from the integration of stress distribution within the active zones, taking into account the stress state from the interaction of raft, piles and subsoil
- $\quad$ vertical load uniformly distributed on raft surface

- flexible raft rests on layered subsoil

The non-linear characteristics of operation of a single pile in the ground medium were described using the curve by Meyer and Kowalów (MK curve) [11], which approximates the results of a static pile test, in the form of:

$$
s\left(N_{2}\right)=\frac{C \cdot N_{g r}}{\kappa}\left[\left(1-\frac{N_{2}}{N_{g r}}\right)^{-\kappa}-1\right]
$$

The presented curve, after determining its characteristic parameters, i.e. the critical load of a pile $\mathrm{N}_{\mathrm{gr}}$ and two constants $\mathrm{C}$ and $\kappa$, enables extrapolation of the load-settlement curve beyond the range of the static test of a pile to the critical load. In the mathematical description, the limit resistance should be understood as the load causing the settlement of the pile without changing its resistance.

The mobilization of resistance around a pile was determined on the basis of two uses of the MK curve $[12,14]$, characterising the behaviour of a single pile in two different states. The first condition is typical for the static load test of a pile, taking into account the skin and base resistance, while the second condition only takes into account base resistance. The parameters of the first state curve were determined by the method of the smallest sum of squares [22]. The parameters of the curve of the second state were determined from the dependencies, in the form of:

$$
s\left(N_{1}\right)=\frac{C_{1} \cdot N_{g r 1}}{\kappa_{1}}\left[\left(1-\frac{N_{1}}{N_{g r 1}}\right)^{-\kappa_{1}}-1\right]
$$

which was adopted on the basis of Meyer's research, for $E_{q}=4 q_{c, s}[9]$ :

$$
\begin{gathered}
N_{g r 1}=\frac{1}{8 \pi} \cdot E_{q} \cdot D^{2} \cdot\left(\frac{h p}{D}\right)^{\frac{1}{3}} \\
C_{1}=\frac{4}{3 \pi \cdot E_{q} \cdot D} \\
\kappa_{1}=\frac{2}{3} \cdot \kappa
\end{gathered}
$$

Mobilization of the skin resistance of the pile was determined from the following dependency:

$$
T(s)=N_{2}(s)-N_{1}(s)
$$

The interaction among raft, piles and subsoil has been determined in the form of partial settlements (Figure 2). These were obtained by appropriate integration of stress distribution in the soil within the limits of active zones (Figure 3). The range of the active zone is understood as the subsoil layer that deforms under the applied load. 


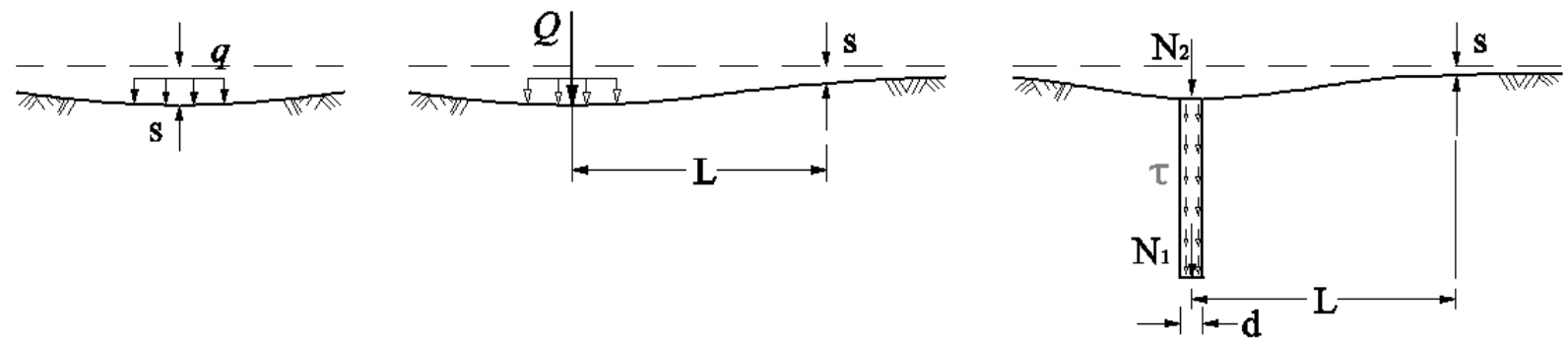

settlement of the field of the discrete raft
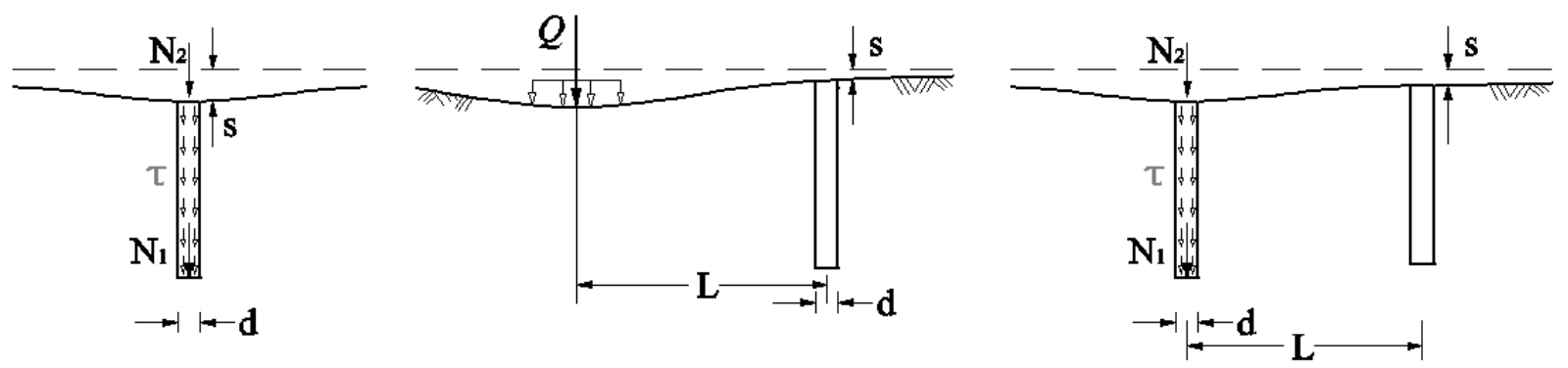

settlement of the pile

Figure 2. Partial settlement modelling interaction between raft, piles and subsoil

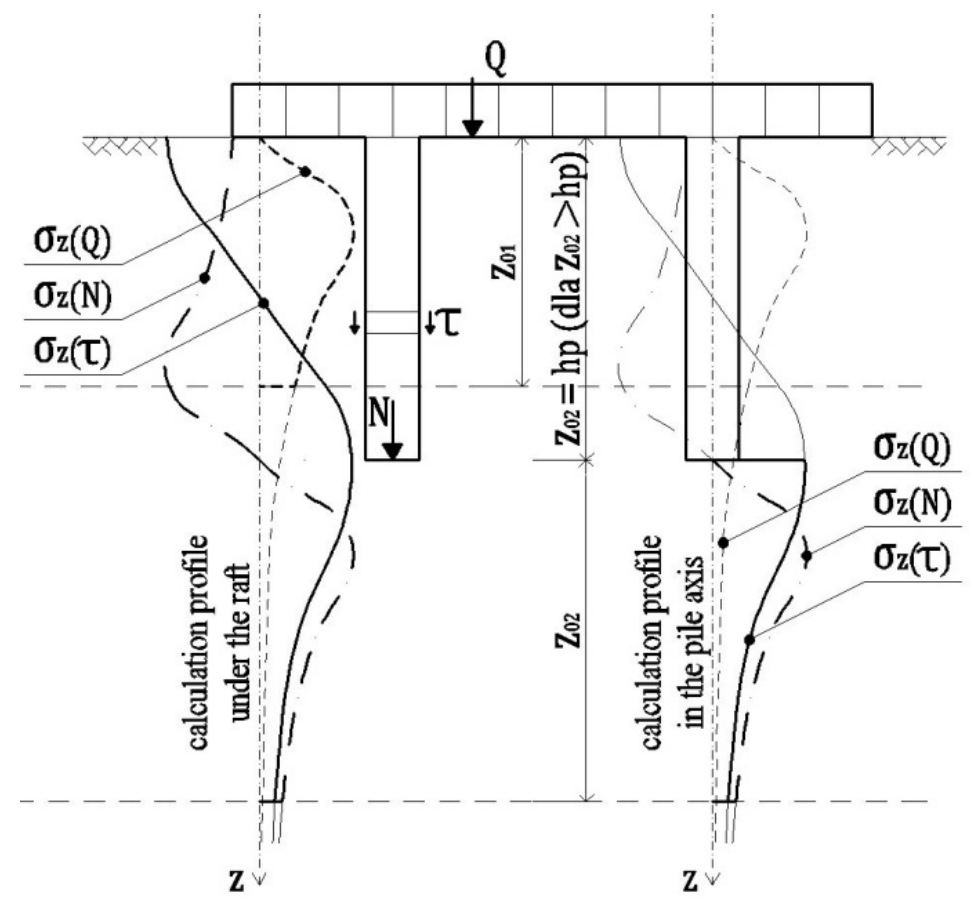

Figure 3. Stress distribution in subsoil including active zones [10] 
Meyer's research shows that the range of the active zone of the mineral soil for the VSS static plate depends on the soil parameters and contact stress $\sigma_{0}$, according to relation [8]:

$$
z_{0}=\frac{1}{2 \cdot \operatorname{tg} \varphi} \cdot \frac{1}{\ln \left(\frac{E_{0}}{\sigma_{0}}\right)} \cdot \frac{\sigma_{0}}{\gamma}
$$

Settlement of the plate, taking into account the active zone $z_{0}$, is obtained from formula:

$$
s=\frac{\sigma_{0}}{E_{0}} \cdot \frac{D \cdot z_{0}}{D+z_{0}}
$$

The above formulae, in accordance with the results of research $[8,13]$, were used in the calculation of spread and pile foundations. For pile foundations, the active zone is determined on the basis of the stress generated in the base of the pile. In the mathematical model, the range of active zones of slab and pile was determined from the following formulae respectively:

$$
\begin{gathered}
z_{01}=\frac{1}{2 \cdot \operatorname{tg} \varphi_{n}} \cdot \frac{1}{\ln \left(\frac{E_{n}}{q}\right)} \cdot \frac{q}{\gamma_{n}} \\
z_{02}=\frac{1}{2 \cdot \operatorname{tg} \varphi_{q}} \cdot \frac{1}{\ln \left(\frac{E_{q}}{q_{C}}\right)} \cdot \frac{q_{C}}{\gamma_{q}}
\end{gathered}
$$

For embankment soils, the range of the active zone equals the entire thickness of anthropogenic soils. We also apply this rule to highly compressible subsoil layers.

Therefore, partial settlement in its general form expresses the relationship:

$$
s=\int_{z_{I}}^{z_{I}} \frac{\sigma_{z}}{E_{0}} d z
$$

where $\mathrm{z}_{\mathrm{I}}, \mathrm{z}_{\mathrm{II}}$ are the limits of the active zone.

The following relationships describing the partial settlements have been determined to express the interaction among raft, piles and subsoil.

The settlement of the elementary field of the raft caused by the load applied on its own field was determined from relation (9), which for the layered subsoil depended on the location of the range of the active zone (Figure 4 ):

- for $\mathrm{z}_{01} \mathrm{\epsilon}<0, \mathrm{~h}_{1}>\rightarrow \mathrm{z}_{01}=\mathrm{z}_{010}\left(\sigma_{\mathrm{z}=0}\right)$

$$
S_{z_{01} \in\left\langle 0, h_{1}\right\rangle}=\frac{\sigma_{z=0}}{E_{1}} \cdot \frac{D \cdot z_{010}}{D+z_{010}}
$$

- for $\mathrm{z}_{01} \mathrm{\epsilon}\left(\mathrm{h}_{1}, \mathrm{~h}_{1}+\mathrm{h}_{2}>\rightarrow \mathrm{z}_{01}=\mathrm{h}_{1}+\mathrm{z}_{011}\left(\sigma_{\mathrm{z}=\mathrm{h} 1}\right)\right.$

$$
S_{z_{01} \in\left(h_{1}, h_{1}+h_{2}\right)}=\frac{\sigma_{z=0}}{E_{1}} \cdot \frac{D \cdot h_{1}}{D+h_{1}}+\frac{\sigma_{z=h_{1}}}{E_{2}} \cdot \frac{D \cdot z_{011}}{D+z_{011}}
$$

- for $\mathrm{z}_{01}>\mathrm{h}_{1}+\mathrm{h}_{2} \quad \rightarrow \mathrm{z}_{01}=\mathrm{h}_{1}+\mathrm{h}_{2}+\mathrm{z}_{012}\left(\sigma_{\mathrm{z}=\mathrm{h} 1+\mathrm{h} 2}\right)$

$$
S_{z_{01}>h_{1}+h_{2}}=\frac{\sigma_{z=0}}{E_{1}} \cdot \frac{D \cdot h_{1}}{D+h_{1}}+\frac{\sigma_{z=h_{1}}}{E_{2}} \cdot \frac{D \cdot h_{2}}{D+h_{2}}+\frac{\sigma_{z=h_{1}+h_{2}}}{E_{3}} \cdot \frac{D \cdot z_{012}}{D+z_{012}}(15)
$$

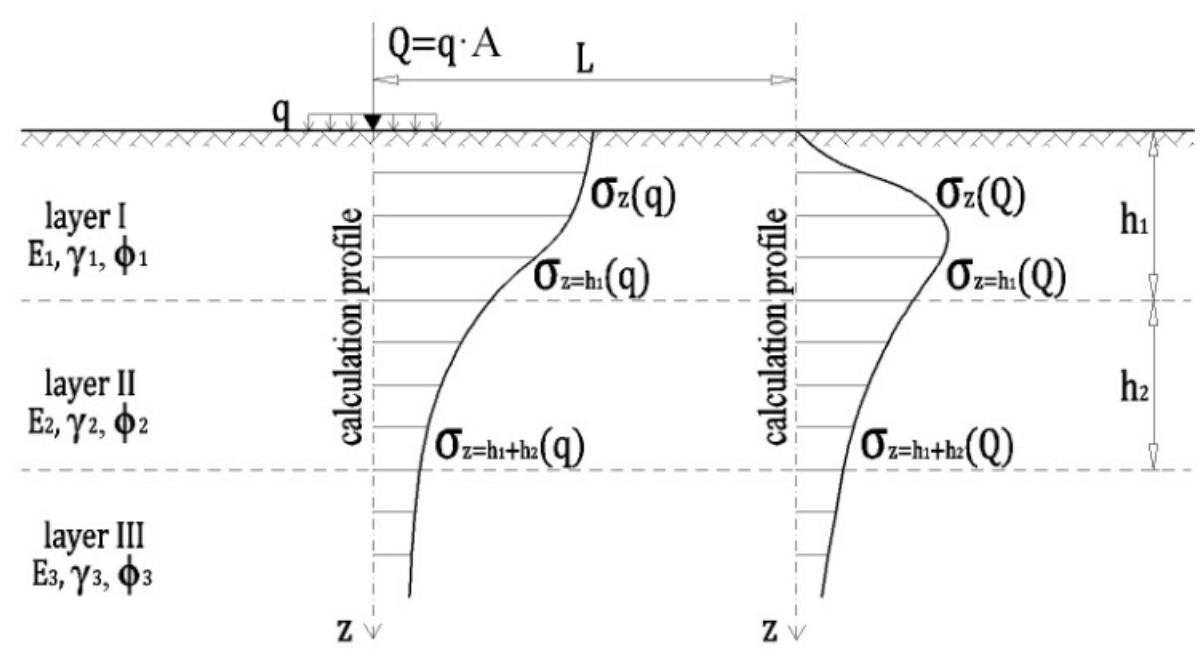

Figure 4. The distribution of stress in the ground under the discrete raft from the load of the self and the adjacent field 
The settlement of the elementary field of the raft caused by the adjacent field load (Figure 4) is determined from the Boussinesq formula [25]:

$$
\sigma_{z}(Q)=\frac{3 \cdot Q \cdot z^{3}}{2 \pi \cdot R^{5}}, \quad R=\sqrt{x^{2}+y^{2}+z^{2}}
$$

which for the layered subsoil is presented in the form:

- for $\mathrm{z}_{01} \epsilon<0, \mathrm{~h}_{1}>\rightarrow \mathrm{z}_{01}=\mathrm{z}_{010}\left(\sigma_{\mathrm{z}=0}\right)$

$$
s_{z_{01} \in\left\langle 0, h_{1}\right\rangle}=\int_{0}^{z_{010}} \frac{\sigma_{z}(Q)}{E_{1}} d z=\frac{Q}{2 \pi \cdot E_{1}}\left[\frac{2}{L}-\frac{3 \cdot z_{010}^{2}+2 \cdot L^{2}}{{\sqrt{z_{010}^{2}+L^{2}}}^{3}}\right]
$$

- for $\mathrm{z}_{01} \mathrm{\epsilon}\left(\mathrm{h}_{1}, \mathrm{~h}_{1}+\mathrm{h}_{2}>\rightarrow \mathrm{z}_{01}=\mathrm{h}_{1}+\mathrm{z}_{011}\left(\sigma_{\mathrm{z}=\mathrm{h} 1}\right)\right.$

$$
\begin{aligned}
S_{z_{01} \in\left(h_{1}, h_{1}+h_{2}\right\rangle} & =\int_{0}^{h_{1}} \frac{\sigma_{z}(Q)}{E_{1}} d z+\int_{h_{1}}^{h_{1}+z_{011}} \frac{\sigma_{z}(Q)}{E_{2}} d z=\ldots \\
& =\frac{Q}{2 \pi \cdot E_{1}}\left[\frac{2}{L}-\frac{3 \cdot h_{1}^{2}+2 \cdot L^{2}}{{\sqrt{h_{1}^{2}+L^{2}}}^{3}}\right]+\ldots \\
& +\frac{Q}{2 \pi \cdot E_{2}}\left[\frac{3 \cdot h_{1}^{2}+2 \cdot L^{2}}{{\sqrt{h_{1}^{2}+L^{2}}}^{3}}-\frac{3 \cdot\left(h_{1}+z_{011}\right)^{2}+2 \cdot L^{2}}{{\sqrt{\left(h_{1}+z_{011}\right)^{2}+L^{2}}}^{3}}\right]
\end{aligned}
$$

- for $\mathrm{z}_{01}>\mathrm{h}_{1}+\mathrm{h}_{2} \rightarrow \mathrm{z}_{01}=\mathrm{h}_{1}+\mathrm{h}_{2}+\mathrm{z}_{012}\left(\sigma_{\mathrm{z}=\mathrm{h} 1+\mathrm{h} 2}\right)$

$$
\begin{aligned}
S_{s_{\Sigma_{01}} h_{1}+t_{2}} & =\int_{0}^{h_{1}} \frac{\sigma_{z}(Q)}{E_{1}} d z+\int_{h_{1}}^{h_{1}+h_{2}} \frac{\sigma_{z}(Q)}{E_{2}} d z+\int_{h_{1}+h_{2}}^{h_{1}+h_{2}+z_{012}} \frac{\sigma_{z}(Q)}{E_{3}} d z=\ldots \\
& =\frac{Q}{2 \pi \cdot E_{1}}\left[\frac{2}{L}-\frac{3 \cdot h_{1}^{2}+2 \cdot L^{2}}{{\sqrt{h_{1}^{2}+L^{2}}}^{3}}\right]+\ldots \\
& +\frac{Q}{2 \pi \cdot E_{2}}\left[\frac{3 \cdot h_{1}^{2}+2 \cdot L^{2}}{{\sqrt{h_{1}^{2}+L^{2}}}^{3}}-\frac{3 \cdot\left(h_{1}+h_{2}\right)^{2}+2 \cdot L^{2}}{{\sqrt{\left(h_{1}+h_{2}\right)^{2}+L^{2}}}^{3}}\right]+\ldots \\
& +\frac{Q}{2 \pi \cdot E_{3}}\left[\frac{3 \cdot\left(h_{1}+h_{2}\right)^{2}+2 \cdot L^{2}}{{\sqrt{\left(h_{1}+h_{2}\right)^{2}+L^{2}}}^{3}}-\frac{3 \cdot\left(h_{1}+h_{2}+z_{012}\right)^{2}+2 \cdot L^{2}}{\sqrt{\left(h_{1}+h_{2}+z_{012}\right)^{2}+L^{2}}}\right]
\end{aligned}
$$

The settlement of the pile caused by the load applied in the head was determined on the basis of the MK curve (2). The settlement of the pile caused by the force generated in the base of the adjacent pile (Figure 2 and Figure 3) is conditional, i.e. it occurs when the difference in length between the piles is smaller than the range of the active pile zone:

- for $\left|h p_{1}-h p_{2}\right| \geq z_{02} \rightarrow s=0$

- for $\left|\mathrm{hp}_{1}-\mathrm{hp}_{2}\right|<\mathrm{z}_{02}$

$$
\begin{aligned}
s & =\int_{h p_{2}-h p_{1}}^{z_{02}} \frac{\sigma_{z}\left(N_{1}\right)}{E_{q}} d z=\ldots \\
& =\frac{N_{1}}{2 \pi \cdot E_{q}}\left[\frac{3 \cdot\left(h p_{2}-h p_{1}\right)^{2}+2 \cdot L^{2}}{\sqrt{\left(h p_{2}-h p_{1}\right)^{2}+L^{2}}}-\frac{3 \cdot z_{02}^{2}+2 \cdot L^{2}}{{\sqrt{z_{02}^{2}+L^{2}}}^{3}}\right]
\end{aligned}
$$

The settlement of the pile caused by stress generated on the skin of the adjacent pile (Figure 2 and Figure 3) is determined from formula:

$$
s=\int_{h p_{2}}^{h p_{1}+z_{02}} \frac{\sigma_{z}\left(\tau_{1}\right)}{E_{q}} d z
$$

$$
\begin{aligned}
s & =\frac{3 \cdot \chi \cdot \tau_{1}}{2 \pi \cdot E_{q}} \cdot\left[\ln \left|\frac{z_{02}+\sqrt{z_{02}^{2}+L^{2}}}{z_{02}+h p_{1}+\sqrt{\left(z_{02}+h p_{1}\right)^{2}+L^{2}}}\right|+\right. \\
& +\frac{z_{02}+h p_{1}}{3 \cdot \sqrt{\left(z_{02}+h p_{1}\right)^{2}+L^{2}}}-\frac{z_{02}}{3 \cdot \sqrt{z_{02}^{2}+L^{2}}}+\ldots \\
& +\ln \left|\frac{\sqrt{h p_{2}^{2}+L^{2}}+h p_{2}}{h p_{2}-h p_{1}+\sqrt{\left(h p_{2}-h p_{1}\right)^{2}+L^{2}}}\right|+\ldots \\
& \left.+\frac{h p_{2}-h p_{1}}{3 \cdot \sqrt{\left(h p_{2}-h p_{1}\right)^{2}+L^{2}}}-\frac{h p_{2}}{3 \cdot \sqrt{h p_{2}^{2}+L^{2}}}\right]
\end{aligned}
$$

The settlement of the pile caused by the load of the elementary field of the raft occurs when the pile length is smaller than the active zone of the raft (Figure 2 and Figure $3)$ and is expressed as a relation:

- for $h p \geq z_{01} \rightarrow \mathrm{s}=0$

- $\quad$ for $h p<\mathrm{z}_{01}$

$$
\begin{aligned}
s & =\int_{h p}^{z_{01}} \frac{\sigma_{z}(Q)}{E_{q}} d z \ldots= \\
& =\frac{Q}{2 \pi \cdot E_{q}}\left[\frac{3 \cdot h p^{2}+2 \cdot L^{2}}{\sqrt{h p^{2}+L^{2}}}-\frac{3 \cdot z_{01}^{2}+2 \cdot L^{2}}{{\sqrt{z_{01}^{2}+L^{2}}}^{3}}\right]
\end{aligned}
$$

The settlement of the elementary field of the raft caused by the force generated in the pile base (Figure 2 and Figure 3 ) occurs when the range of the active zone of the pile is greater than its length and therefore:

- for $\mathrm{hp} \geq \mathrm{z}_{02} \rightarrow \mathrm{s}=0$

- $\quad$ for $h p<z_{02}$

$$
\begin{aligned}
s & =\int_{-h p}^{z_{02}} \frac{\sigma_{z}\left(N_{1}\right)}{E_{s r}} d z=\ldots \\
& =\frac{N_{1}}{2 \pi \cdot E_{s r}}\left[\frac{3 \cdot h p^{2}+2 \cdot L^{2}}{\sqrt{h p^{2}+L^{2}}}-\frac{3 \cdot z_{02}^{2}+2 \cdot L^{2}}{{\sqrt{z_{02}^{2}+L^{2}}}^{3}}\right]
\end{aligned}
$$

The settlement of the elementary field of the raft caused by the stress generated on the pile skin (Figure 2 and Figure 3 ) is given by formula: 


$$
\begin{aligned}
S & =\int_{0}^{h p+z_{02}} \frac{\sigma_{z}(\tau)}{E_{s r}} d z=\ldots \\
& =\frac{3 \cdot \chi \cdot \tau}{2 \pi \cdot E_{s r}} \cdot\left[\ln \mid \frac{z_{02}+\sqrt{z_{02}^{2}+L^{2}}}{z_{02}+h p+\sqrt{\left(z_{02}+h p\right)^{2}+L^{2}} \mid+\ldots}\right. \\
& +\frac{z_{02}+h p}{3 \cdot \sqrt{\left(z_{02}+h p\right)^{2}+L^{2}}}-\frac{z_{02}}{3 \cdot \sqrt{z_{02}^{2}+L^{2}}}+\ldots \\
& \left.+\ln \left|\frac{L}{\sqrt{h p^{2}+L^{2}}-h p}\right|-\frac{h p}{3 \cdot \sqrt{h p^{2}+L^{2}}}\right]
\end{aligned}
$$

\section{Solution of the Mathematical Model}

Knowing the relationships describing the interaction between the elastic raft on the subsoil and the piles, the settlement of the subsoil and piles was determined according to formula:

$$
\left\{\begin{array}{c}
\left\{s_{R}\right\} \\
\left\{s_{P}\right\}
\end{array}\right\}=\left[\begin{array}{cccc}
{[W R R]} & {[0]} & {\left[W N_{1} R\right]} & {[W \tau R]} \\
{[W R P]} & {\left[W N_{2} P\right]} & {\left[W N_{1} P\right]} & {[W \tau P]}
\end{array}\right] \cdot\left\{\begin{array}{c}
\left\{R_{R}\right\} \\
\left\{N_{2}\right\} \\
\left\{N_{1}\right\} \\
\{\tau\}
\end{array}\right\}
$$

In the mathematical model discussed above, the raft rests on elastic supports, modelling layered subsoil and piles, with the vertical stiffness of the supports expressed in the form:

$$
\left\{\begin{array}{l}
\left\{k_{R}\right\} \\
\left\{k_{p}\right\}
\end{array}\right\}=\left\{\begin{array}{l}
\left\{R_{R} / s_{R}\right\} \\
\left\{R_{P} / s_{P}\right\}
\end{array}\right\}
$$

The proposed method is to determine the distribution of the contact stress of the raft and piles with the subsoil in such a way that the deflections of the raft calculated on the basis of differential equation (1) and the settlement of the subsoil with piles (25) were the same with the assumed accuracy. The above equation is solved using the numerical method.

The developed mathematical model enables the analysis of the geotechnical conditions of piled raft foundations, taking into account the static load test curve as a boundary condition of the solution. The mathematical model enables the analysis of load distribution between the raft and piles, and the influence of piles on the reduction and equalisation of raft settlement for given geotechnical conditions.

\section{Examples of Calculations}

A review of the solutions obtained with the mathematical model in question was carried out for the combined pile raft foundation with five piles. The analysis was performed for two types of piles deposited in different soil conditions (Table 1 and Table 2).

The first pile is a non-displacement drilled pile (pile no. I), while the second pile is a driven pile (pile no. II).

Geometric data of piles:

Pile no. I- $h p=10.0 \mathrm{~m}, D=0.60 \mathrm{~m}$

Pile no. II- $h p=13.5 \mathrm{~m}, D=0.508 \mathrm{~m}$

Table 1. Geotechnical parameters - pile no. I

\begin{tabular}{|l|l|l|}
\hline Type of soil & $\begin{array}{l}\text { Thickness of } \\
\text { layer }[\mathrm{m}]\end{array}$ & $\begin{array}{l}\text { Young's modulus } \\
E_{0}[\mathrm{MPa}]\end{array}$ \\
\hline silty clay & 3.0 & 7.0 \\
\hline sandy silty clay & 6.5 & 24.6 \\
\hline silty clay & - & 12.5 \\
\hline
\end{tabular}

Table 2. Geotechnical parameters - pile no. II

\begin{tabular}{|l|l|l|}
\hline Type of soil & $\begin{array}{l}\text { Thickness of } \\
\text { layer }[\mathrm{m}]\end{array}$ & $\begin{array}{l}\text { Young's modulus } \\
E_{0}[\mathrm{MPa}]\end{array}$ \\
\hline silty clay & 5.0 & 7.0 \\
\hline fine sand & 7.0 & 56.4 \\
\hline fine sand & - & 60.0 \\
\hline
\end{tabular}

The results of the static load tests were used to determine the parameters of the MK curve, together with the mobilization of the skin and base resistances of the piles (Figure 5).
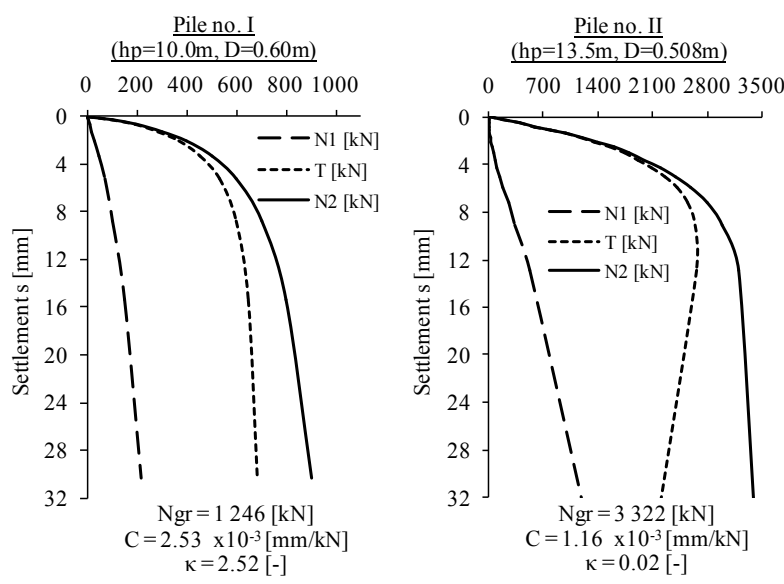

Figure 5. Skin and base resistance mobilization of piles

A review of the solution was carried out on the example of a $4.5 \times 7.0 \mathrm{~m}$ raft, which rests on the subsoil and five piles. The locations are shown in Figure 6.

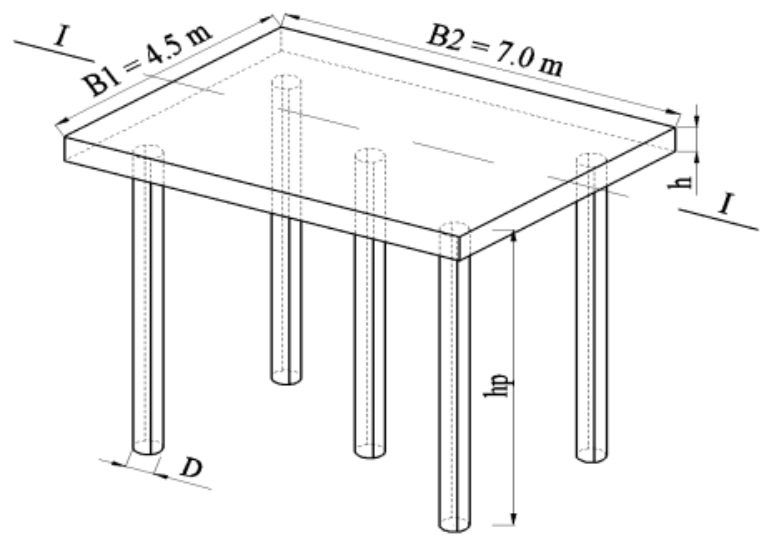

Figure 6. Scheme of the analysed foundation 


\subsection{Analysis of Settlement and Deflection of the Combined Pile Raft Foundation}

The analysis of the impact of bending stiffness of the raft is presented in Figure 7 and Figure 8. The review of the obtained results also takes into account the type of pile expressed in the load-settlement relation. Based on the obtained results of raft settlement, it can be concluded that for a given location and pile spacing in a group, the reduction of raft stiffness affects the increase of the load transmitted by the central pile. This illustrates the largest settlement in the middle of the raft, which is also a result of the work of a given pile group. As expected, the increased stiffness of the raft contributed to the compensation of settlement and increased uniformity of the load of corner piles with the central pile. This results from the stress state in the ground medium, the reduction of deflection of the raft and, thus, the compensation of the settlement of the subsoil.

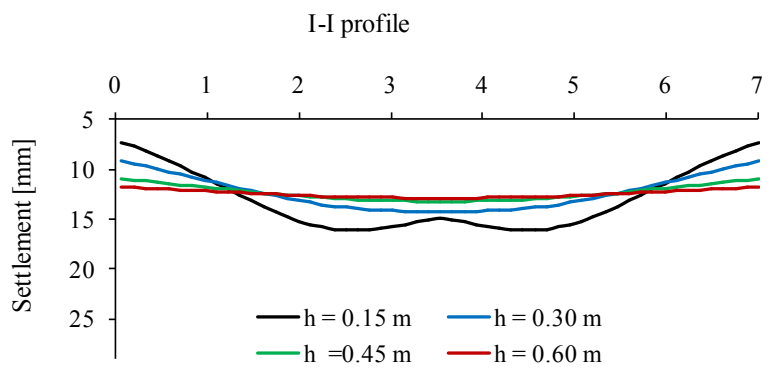

Figure 7. Impact of bending stiffness of the raft on its settlement and deflection (qo=125kPa, pile no. I)

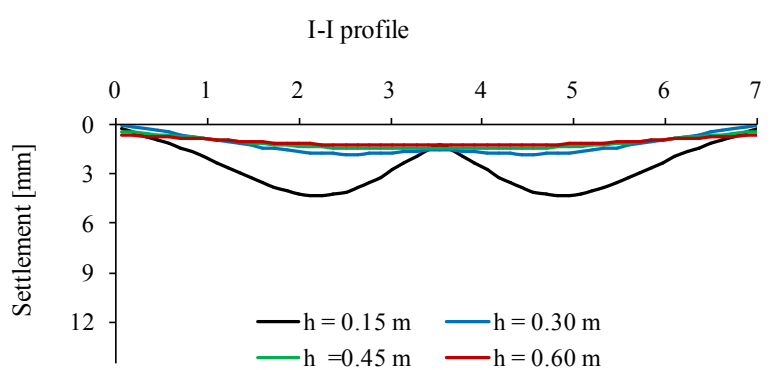

Figure 8. Impact of bending stiffness of the raft on its settlement and deflection ( $\mathrm{qo}=125 \mathrm{kPa}$, pile no. II)

The factor influencing the settlement of the raft is, of course, piles. Their influence depends on the settlement of a given pile in the group under the impact of the load applied to the head, resulting from its location in the group, the load of the raft, and its bending stiffness in the given ground conditions.

\subsection{Analysis of the Load-Settlement Curve of a Pile Working in a Group of Piles under the Raft}

The calculations carried out allow us to state that the settlement of piles working in a group, taking into account the synergy of the raft, is different from that during a static load test. The reason for this phenomenon can be found in the stress state in the ground medium, resulting from the impact of individual piles on each other. The settlement of piles in a group depends, apart from the load applied to their heads, on their interaction, which affects their settlement as a whole (Figure 9 and Figure 10). In the analysed example, due to the range of the active zone of the raft, the raft-subsoil contact stress does not affect the settlement of the piles.
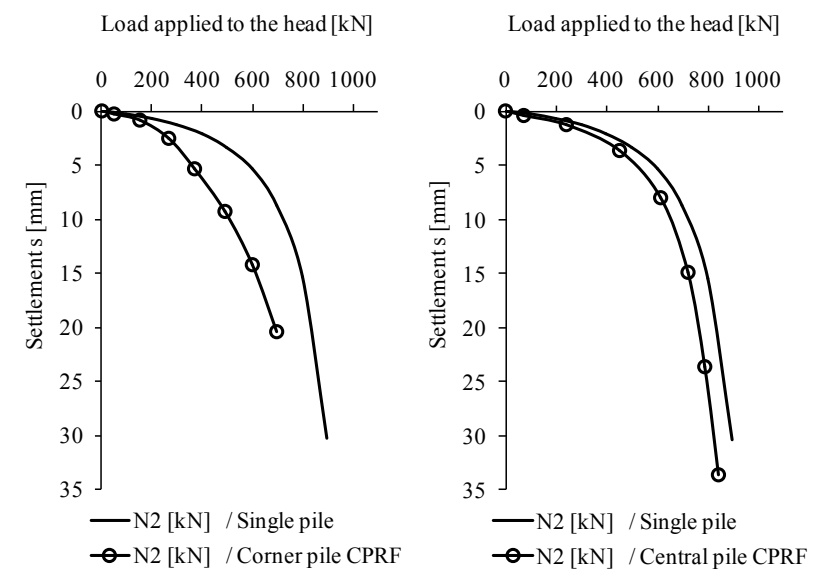

Figure 9. Comparison of load-settlement curve during static load test and during load transmitted to the foundation (raft thickness $0.15 \mathrm{~m}$, pile no.I)
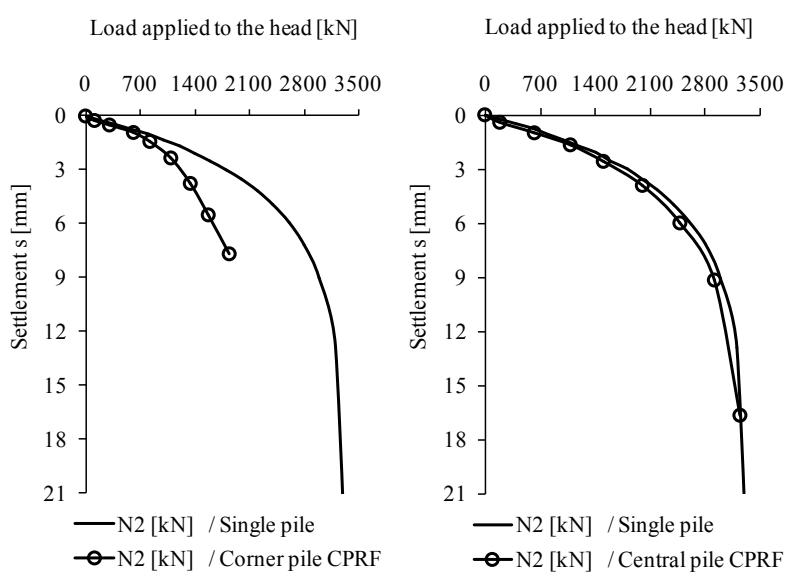

Figure 10. Comparison of load-settlement curve during static load test and during load transmitted to the foundation (raft thickness $0.15 \mathrm{~m}$, pile no.II)

In this example, the central pile is more loaded, showing a greater settlement than the corner pile. Resistance around the central pile and, therefore, the stress generated by it in the ground medium, have a greater impact on the settlement of adjacent piles. This is reflected in the greater divergence in the settlement of corner piles compared with the settlement of a single pile.

\subsection{Analysis of the Contribution of Piles in Transferring the Load}

The analysis of load distribution between the raft and piles is inextricably linked to the type of piles and 
geotechnical conditions. The share of piles in transferring the load to the subsoil is determined by the load-settlement curve of the piles and the bending stiffness of the raft, taking into account the geotechnical conditions. Figure 11 and Figure 12 show the impact of the pile type and the stiffness of the raft on the load distribution. The contribution of piles in transferring the load to the subsoil increases with the bending stiffness of the raft.

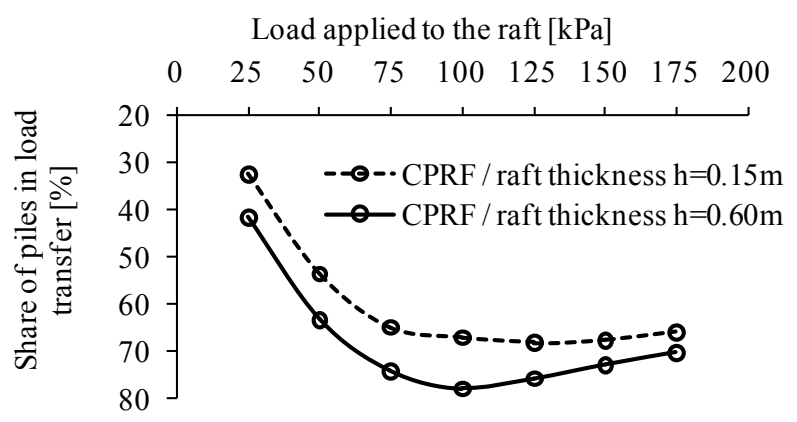

Figure 11. Impact of bending stiffness of the raft on the share of piles in load transfer (pile no. I)

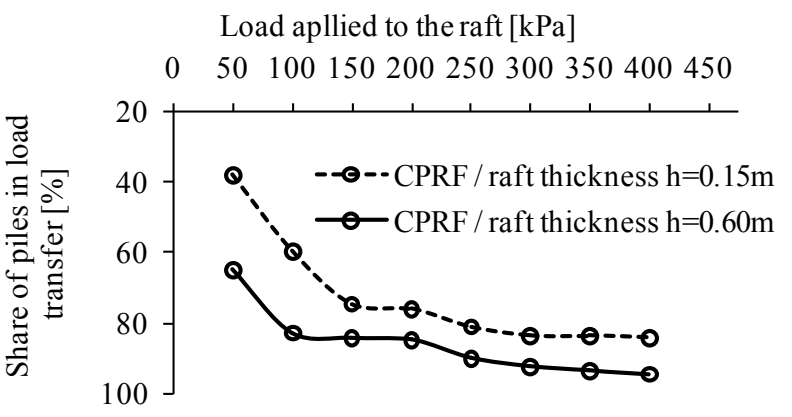

Figure 12. Impact of bending stiffness of the raft on the share of piles in load transfer (pile no. II)

\section{Application}

The correctness of the assumptions of the mathematical model was based on the results of field research [21,23]. The research included geodetic monitoring of settlement of two tanks of the Sewage Treatment Plant Complex, i.e. the Emergency tank and Final cleaning tank (Figure 13 and Figure 14). The foundations of these tanks were designed and constructed as combined pile raft foundations and have diameters of $13 \mathrm{~m}$ and $17 \mathrm{~m}$. The tanks were placed on CFA (Continuous Flight Augering) piles with diameters of $\phi 400 / 600 \mathrm{~mm}$ and lengths of $9.5-12 \mathrm{~m}$.

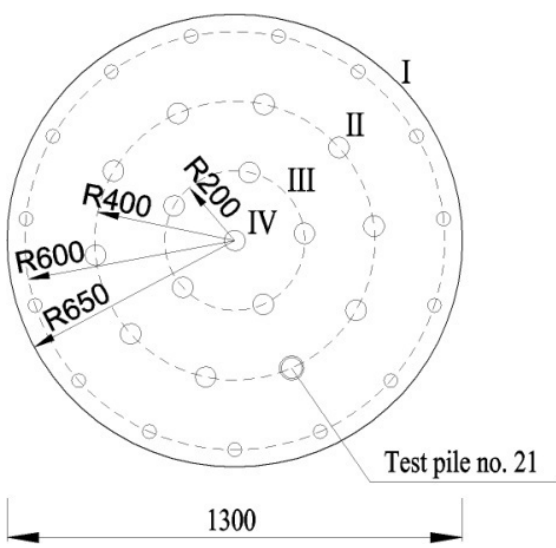

Diameters and lengths of piles:

I $\quad-15$ CFA piles $\phi 400 \mathrm{~mm}, \mathrm{hp}=9.5 \mathrm{~m}$

II $-10 \mathrm{CFA}$ piles $\phi 600 \mathrm{~mm}, \mathrm{hp}=10.0 \mathrm{~m}$

III -5 CFA piles $\phi 600 \mathrm{~mm}, \mathrm{hp}=9.5 \mathrm{~m}$

IV -1 CFA pile $\phi 600 \mathrm{~mm}, \mathrm{hp}=9.5 \mathrm{~m}$

Figure 13. Layout of piles in foundation of Emergency tank [21]

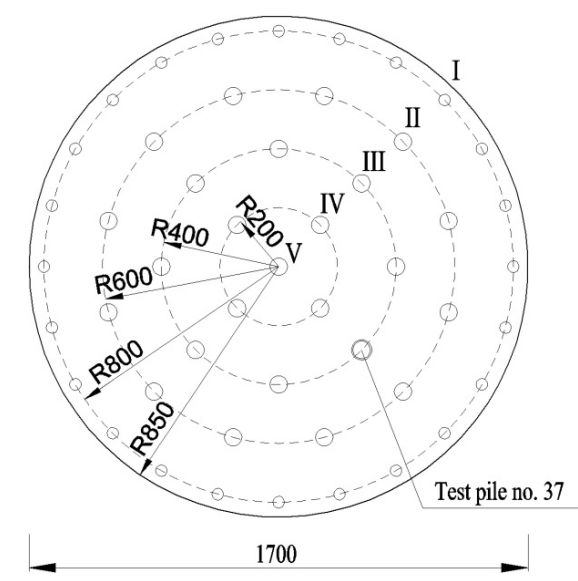

Diameters and lengths of piles:

$$
\begin{aligned}
& \text { I }-24 \text { CFA piles } \phi 400 \mathrm{~mm}, \mathrm{hp}=12.0 \mathrm{~m} \\
& \text { II }-12 \text { CFA piles } \phi 600 \mathrm{~mm}, \mathrm{hp}=12.0 \mathrm{~m} \\
& \text { III }-8 \text { CFA piles } \phi 600 \mathrm{~mm}, \mathrm{hp}=12.0 \mathrm{~m} \\
& \text { IV }-4 \text { CFA piles } \phi 600 \mathrm{~mm}, \mathrm{hp}=12.0 \mathrm{~m} \\
& \text { V }-1 \text { CFA pile } \phi 600 \mathrm{~mm}, \mathrm{hp}=12.0 \mathrm{~m}
\end{aligned}
$$

Figure 14. Layout of piles in foundation of Final cleaning tank [21]

Three basic geotechnical layers were distinguished. Anthropogenic embankment occurs on the surface of the area. This embankment has been partially consolidated by the coal storage site that used to exist here. In the second layer, mainly clayey sands and sandy clays in a very soft state are found, with stratification of non-cohesive loose or medium-compacted soils. Below, in a separate third layer, silty clay and sandy silt exist in the firm and soft state boundary.

The analysed objects have geotechnical profiles (Table 3 and Table 4), with the results of static load tests made on the foundation raft plan of each tank (Figure 15). 
Table 3. Geotechnical profile - Emergency tank [21,23]

\begin{tabular}{|c|c|c|c|}
\hline Layer number & Type of soil & Ground condition $I_{L} / I_{D}$ & Oedometric modulus $E_{\text {oed }}[\mathrm{MPa}]$ \\
\hline I & Fill & $0.3(0.5)$ & 20 \\
\hline IIb & clayey sand, sandy clay & 0.4 & 20 \\
\hline IIa & clayey sand, sandy clay & 0.6 & 42 \\
\hline IIc & fine sand, medium sand & $\leq 0.3$ & 20 \\
\hline IIa & clayey sand, sandy clay & 0.6 & 35 \\
\hline IIIa & silt & 0.25 & 22 \\
\hline IIIb & silty clay, sandy silt & 0.25 & 31 \\
\hline IIIc & silty clay, silty sand & 0.1 & \\
\hline
\end{tabular}

Table 4. Geotechnical profile - Final cleaning tank $[21,23]$

\begin{tabular}{|c|c|c|c|}
\hline Layer number & Type of soil & Ground condition $I_{L} / I_{D}$ & Oedometric modulus $E_{\text {oed }}[\mathrm{MPa}]$ \\
\hline I & fill & $0.3(0.5)$ & 20 \\
\hline IId & medium sand & 0.5 & 100 \\
\hline IIa & clayey sand & 0.6 & 20 \\
\hline IIIb & silty clay, silty sand & 0.25 & 22 \\
\hline IIIc & silty clay, silty sand & 0.1 & 31 \\
\hline
\end{tabular}

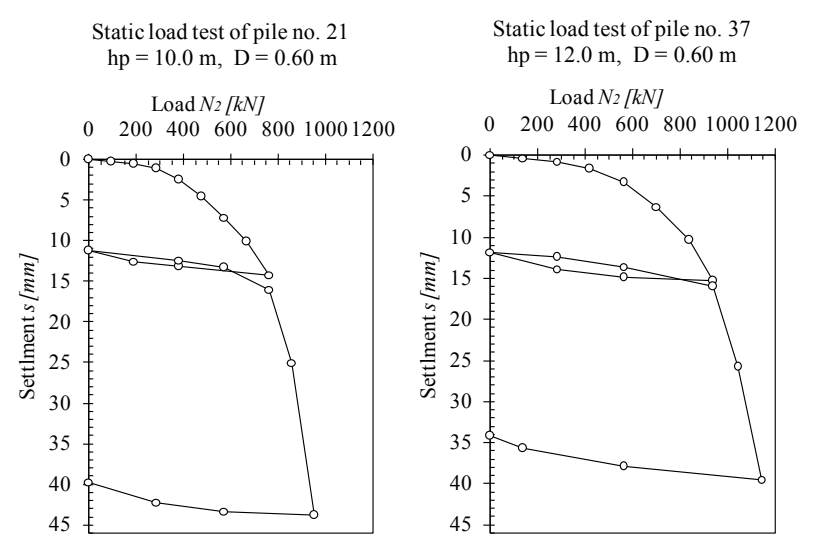

Figure 15. Results of the static load test of pile no. 21 of the Emergency tank and pile no. 37 of the Final cleaning tank [21]

Measuring benchmarks were installed on the tank foundations, located along the perimeter of the foundation raft. The settlement control was carried out during the water test. The obtained settlement results were used to verify the presented mathematical model. The comparison between calculated and measured settlements is presented in Figure 16 and Figure 17.

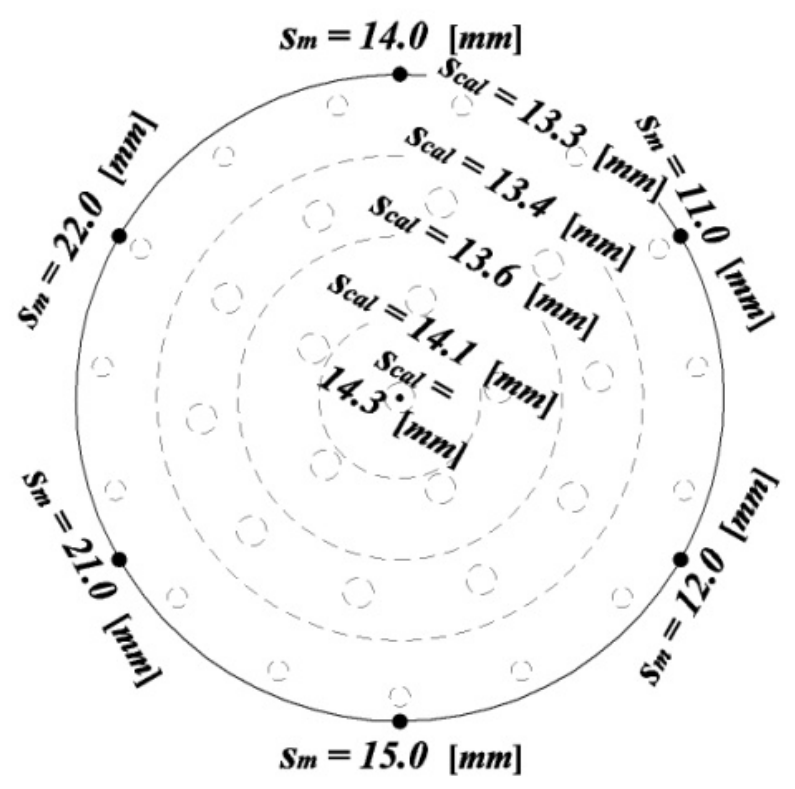

Figure 16. Calculated and measured settlement of foundation raft of Emergency tank 


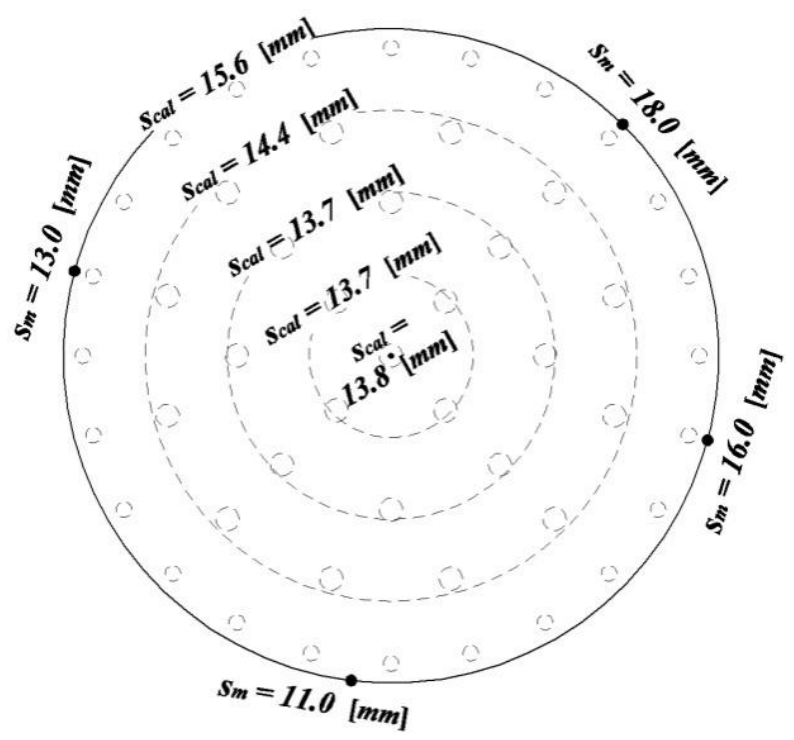

Figure 17. Calculated and measured settlement of foundation raft of Final cleaning tank

Measurements of geodetic settlements were located on the external outline of the foundation. On the basis of measurements made, uneven displacement of the two benchmarks of the Emergency tank can be observed, which could be due to local deterioration of ground conditions. The obtained results of settlement calculations and their significant compliance with the majority of measured values verify the correctness of the adopted assumptions.

On the basis of calculations made for the foundation of the Final cleaning tank, we can observe the largest settlements around the perimeter of the raft edge. This is due to the diversity of piles in the group, i.e. the external perimeter is made of piles with lower bearing capacity and stiffness compared to the piles inside the group. The above design assumption made it possible to reduce settlement in the central part of the raft. It should be noted that the parameters of the MK curve for piles located around the perimeter were estimated on the basis of the results of a load test of a pile inside a group. We do not have the results of the load test of the external pile, which affects the accuracy of the obtained results.

\section{Discussion}

The subject of the research was the analysis of the synergy of a raft with a group of piles in transferring vertical load to the ground.

During the implementation of the above task, a method of calculation of combined pile raft foundations based on the results of a static test pile load was proposed. The authors of the article believe that the proposed mathematical model, based on the results of the static load tests, has practical significance, taking into account the EuroCode 7 method of pile design on the basis of the results of static load tests. The EC7 standard also states that empirical and analytical methods of pile design require verification based on static tests. Therefore, given that the current trend in the design of piling works considers the use of databases of static load tests as important, the authors argue that it is imperative to develop methods based directly on the results of static pile tests.

The mathematical model presented in the paper also takes into account the interaction of raft, piles and subsoil. As a result of the calculations carried out, we obtained the settlement and deflection of the raft, and determined the load distribution transmitted by the raft and individual piles in the group.

\section{Conclusions}

On the basis of the developed mathematical model, the systematic review of the solution, and the calculation of the foundations, the following conclusions were formulated:

1. The presented mathematical model determines the relationship between the load and settlement of combined pile raft foundations. The presented solution introduces into the calculations of the load-settlement relationship from the static load test, which brings it closer to the physical model.

2. The solution of the mathematical model was obtained on the basis of numerical methods and boundary conditions, which result from the synergy of a raft with a group of piles.

3. The analysis and research results confirm that it is possible to use the load-settlement curve from the static pile test to analyse the load-settlement curve of a pile occurring in a pile group under the raft.

4. The contribution of piles in transferring the load is inextricably linked with the type of pile. The performance characteristics of the piles and raft determine the share of piles in the transmission of the load to the ground.

5. The contribution of piles in transferring the load increases as the load increases to a certain value, exceeding which initiates the process of reducing the share of piles in transferring the load to the ground. The reason for this phenomenon can be found in the non-linear characteristics of the pile work in the ground.

\section{Notation}

\section{Latin letters}

$B$ - dimensions of foundation raft [m]

$C-$ a constant value representing the aggregated soil reaction modulus $[\mathrm{mm} / \mathrm{kN}]$

$D$ - pile diameter $[\mathrm{m}]$

$D_{b}$ - bending stiffness of the raft $[\mathrm{kNm}]$ 
$E_{0}$ - modulus of linear deformation of ground [MPa]

$E_{b}$ - modulus of elasticity of concrete [MPa]

$E_{n}-$ modulus of linear deformation of ground of geotechnical layer $n=1,2,3[\mathrm{MPa}]$

$E_{q}$ - modulus of linear deformation of ground under pile base $[\mathrm{MPa}]$

$E_{s r}$ - average modulus of linear deformation of ground along pile skin and active pile zone [MPa]

$E_{t}$ - modulus of linear deformation of ground along pile skin [MPa]

$h$ - thickness of raft [m]

$h p$ - pile length [m]

$I_{D}$ - density index

$I_{L}$ - liquidity index

$k$ - vertical stiffness of elastic supports modelling subsoil or pile $[\mathrm{kPa} / \mathrm{m}]$

$L$ - distance between calculation profile and point of application of load [m]

$m$ - number of elementary fields of the discrete foundation raft

$n$ - number of piles in the group

$N_{l}$ - base resistance of pile [kN]

$\mathrm{N}_{2}-$ load applied to pile head [kN]

$N_{g r}-$ critical load [kN]

$q$ - contact pressure of raft with subsoil [kPa]

$Q$ - load of raft field applied to the subsoil in the form of

a concentrated force $[\mathrm{kN}]$

$q_{0}-$ load applied to raft $[\mathrm{kPa}]$

$q_{c, s}-$ static point resistance $(\mathrm{CPT})[\mathrm{kPa}]$

$s$ - settlement of subsoil/piles and deflection of raft [m]

$s_{c a l}-$ calculated settlement [mm]

$s_{m}$ - measured settlement [mm]

$T$ - total skin resistance of pile $[\mathrm{kN}]$

$x, y, z$ - axes of a rectangular coordinate system

$z_{0}$ - range of active zone [m]

$z_{01}-$ range of active zone of foundation raft [m]

$z_{02}$ - range of active zone of pile [m]

\section{Greek letters}

$\gamma$ - volume weight of ground $\left[\mathrm{kN} / \mathrm{m}^{3}\right]$

$\gamma_{n}-$ volume weight of ground of geotechnical layer $n=1,2,3\left[\mathrm{kN} / \mathrm{m}^{3}\right]$

$\gamma_{q}$ - volume weight of ground under pile base $\left[\mathrm{kN} / \mathrm{m}^{3}\right]$

$\kappa$ - dimensionless constant

$\lambda$ - pile circumference $[\mathrm{m}]$

$v$ - Poisson's ratio

$\sigma_{z}(\ldots)$ - vertical component of soil stress $[\mathrm{kPa}]$

$\tau, t-$ skin resistance of pile $[\mathrm{kPa}]$

$\phi$ - angle of internal friction of ground $\left[^{\circ}\right]$

$\phi_{n}$ - angle of internal friction of ground of geotechnical layer $n=1,2,3\left[^{\circ}\right]$ $\left[{ }^{\circ}\right]$

$\phi_{q}$ - angle of internal friction of ground under pile base

\section{Matrix and vectors}

[0] - null matrix

$\left\{k_{P}\right\}$ - vector of vertical stiffness of elastic supports modelling piles

$\left\{k_{R}\right\}$ - vector of vertical stiffness of elastic supports modelling subsoil

$\left\{N_{l}\right\}$ - vector of base resistance of piles

$\left\{N_{2}\right\}$ - vector of load applied to pile head

$\left\{R_{P}\right\}$ - vector of quotients of load applied to pile heads in the area of elementary field

$\left\{R_{R}\right\}$ - vector of contact pressure of raft fields with subsoil

$\left\{s_{P}\right\}$ - vector of settlement of piles in the calculation profiles of raft fields

$\left\{s_{R}\right\}$ - vector of settlement of subsoil in the calculation profiles of raft fields

$\{\tau\}-$ vector of skin resistance of piles

$\left[W N_{l} P\right]$ - matrix of impact factors of base resistance of piles on the settlement of piles

$\left[W N_{l} R\right]$ - matrix of impact factors of base resistance of piles on the settlement of raft fields

$\left[\mathrm{WN}_{2} \mathrm{P}\right]-$ matrix of impact factors of load applied to pile heads on the settlement of piles

$[W R P]$ - matrix of impact factors of contact pressure of raft with subsoil on the settlement of piles

$[W R R]$ - matrix of impact factors of contact pressure of raft with subsoil on the settlement of raft fields

$[W \tau P]$ - matrix of impact factors of skin resistance of piles on the settlement of piles

$[W \tau R]$ - matrix of impact factors of skin resistance of piles on the settlement of raft fields

\section{REFERENCES}

[1] Butterfield R., Banerjee P.K.: The elastic analysis of compressible piles and pile groups. Geotechnique, Vol. 21, No. 1, pp. 43-60, 1971

[2] Cichocki P.: Analiza współpracy fundamentu płytowo-palowego $\mathrm{z}$ podłożem gruntowym $\mathrm{z}$ uwzględnienie oporu pobocznicy i podstawy pala wywołanych osiadaniem. Ph.D. Dissertation. West Pomeranian University of Technology in Szczecin, 2018

[3] Clancy P., Randolph M.F.: An approximate analysis procedure for piled raft foundations. International Journal for Numerical Methods in Geomechanics, Vol. 17, pp. 849-869, 1993

[4] El Gendy M., Hanisch J., Kany M.: Empirische nichtlineare Berechnung von Kombinierten Pfahl-Plattengründungen (KPP). Bautechnik, Vol. 83, No. 6, pp. 604-617, 2006

[5] Griffiths D.V., Clancy P., Randolph M.F.: Piled raft foundation analysis by finite elements. Computer Methods and Advances in Geomechanics, Balkema, Rotterdam, Vol. 1, pp. 1153-1157, 1991

[6] Katzenbach R., Gutberlet Ch., Bachmann G.: Soil-Structure 
Interaction aspects for ultimate limit state design of complex foundations. ISGSR2007 First International Symposium on Geotechnical Safety \& Risk, Shanghai, pp. 585-596, 2007

[7] Katzenbach R., Schmitt A., Turek J.: Assessing Settlement of High-Rise Structures by 3D Simulations. Computer-Aided Civil and Infrastructure Engineering, Vol. 20, pp. 221-229, 2005

[8] Meyer Z.: Obliczenia inżynierskie osiadania fundamentów. Wydawnictwo ZAPOL, Szczecin, 2012

[9] Meyer Z.: Wykorzystanie wyników testu statycznego pala do określenia mobilizacji oporu pobocznicy. XXIII Seminarium Naukowe z cyklu Regionalne Problemy Inżynierii Środowiska, Szczecin, s. 57-68, 2016

[10] Meyer Z., Cichocki P.: Analiza sprężystej płyty na palach z uwzględnieniem krzywej aproksymującej wyniki testów statycznych pali. Inżynieria Morska i Geotechnika, Nr 3, s. $117-124,2017$

[11] Meyer Z., Kowalów M.: Model krzywej aproksymującej wyniki testów statycznych pali. Inżynieria Morska Geotechnika, Nr 3, s. 438-441, 2010

[12] Meyer Z., Szmechel G.: Określenie oporów pobocznicy pala na podstawie próbnych statycznych obciążeń pali. Inżynieria Morska i Geotechnika, Nr 3, s. 441-444, 2015

[13] Meyer Z., Żarkiewicz K.: Wykorzystanie wzoru na osiadanie płyty statycznej do określenia naprężenia pod podstawa kolumny betonowej. Inżynieria Morska i Geotechnika, Nr 1, s. 30-35, 2014

[14] Meyer Z., Żarkiewicz K.: Analiza mobilizacji oporu pobocznicy i podstawy pala na podstawie interpretacji badań modelowych. Inżynieria Morska i Geotechnika, Nr 3, s. $350-354,2015$

[15] Ottaviani M.: Three-dimensional finite element analysis of vertically loaded pile groups. Geotechnique, Vol. 25, No. 2, pp. 159-174, 1975

[16] Pietrzak J., Rakowski G., Wrześniowski K.: Macierzowa analiza konstrukcji. PWN, Warszawa-Poznań, 1979

[17] Poulos H.G., Davis E.D.: Pile foundations analysis and design. John Wiley \& Sons, New York, 1980

[18] Randolph M.F.: Design methods for pile groups and piled rafts. Proc. XIII ICSMFE, New Delhi, pp. 61-82, 1994

[19] Reul O., Randolph M.F.: Piled rafts in overconsolidated clay: comparison of in situ measurements and numerical analyses. Geotechnique, Vol. 53, No. 3, pp. 301-315, 2003

[20] Reul O., Randolph M.F.: Design Strategies for Piled Rafts Subjected to Nonuniform Vertical Loading. Journal of Geotechnical and Geoenvironmental Engineering, Vol. 130, No. 1, pp. 1-13, 2004

[21] Słabek A.: Współdziałanie płyty fundamentowej na palach z podłożem gruntowym. Ph.D. Dissertation. Gdańsk University of Technology, 2003

[22] Szmechel G.: Określenie nośności granicznej pali na podstawie próbnych obciążeń statycznych w ograniczonym zakresie. Ph.D. Dissertation. West Pomeranian University of Technology in Szczecin, 2014
[23] Tejchman A., Gwizdała K., Słabek A.: Investigations of settlement of piled raft foundation. Fifth International Conference on Case Histories in Geotechnical Engineering. New York, 2004

[24] Terzaghi K., Peck R.B.: Soil Mechanics in Engineering Practice. John Wiley \& Sons, New York, 1948

[25] Wiłun Z.: Zarys Geotechniki. WKiŁ. Warszawa, 2005 